\title{
PEDAGOGICAL CONDITIONS OF EDUCATION OF VALUE ATTITUDE TO THE LIVING NATURE OF MIDDLE SCHOOL STUDENTS
}

\begin{abstract}
Nadiya Dira ${ }^{1}$
${ }^{1}$ Assistant of the Pedagogy Department, National University of Nature Management and Bioresources of Ukraine, Kyiv, Ukraine, e-mail: dira.nadija90@gmail.com, ORCID: https://orcid.org/0000-0001-5523-7943

Abstract. The article considers the pedagogical conditions of education of middle school students in the value attitude to wildlife, different approaches of scientists to the definition of this term. The specifics and essences of the concepts "condition" and "pedagogical condition" of the formation of this neoplasm are determined. The own definition of pedagogical conditions of education of the value relation to the living nature of pupils of middle school age is formed. Using the mathematical and statistical analysis of the method of expert evaluation, the pedagogical conditions of our study were experimentally established. It is substantiated that the education of ecological culture in middle school students and its such a separate component as a value attitude to wildlife should be carried out based on modern methodological approaches, which we have identified on the basis of expert assessment. It is noted that the level of ecological culture is to improve human qualities. It is indicated that pedagogical science is the main tool for influencing human consciousness. There are some differences in the results of expert evaluation of teachers in connection with the age and gender characteristics of students.
\end{abstract}

Keywords: pedagogical conditions, upbringing, values to wildlife, middle school students.

JEL Classification: I 24, I 29

Formulas: 0; fig.: 0; tabl.: 1; bibl.: 13

Introduction. In the process of educating the values of wildlife of middle school students an important place is occupied by pedagogical conditions that positively affect self-improvement, creative self-realization, professional development and continuous improvement of skills, and values to the world become a social need of society.

Literature review. Analysis of psychological, pedagogical, philosophical and scientific literature found that there are different approaches to the definition of the term "pedagogical conditions". The dictionary-reference book on professional pedagogy defines that pedagogical conditions are "circumstances on which the integral productive pedagogical process of professional training of specialists, which is mediated by the activity of an individual, a group of people, depends and takes place" [1].

According to the interpretation in the philosophical context, the term "condition" is defined as a category of universal relation of a thing to the factors and factors due to which it arises and exists [2]. Interpreting this definition, we can conclude that it is the conditions that make up the environment in which a certain phenomenon and process arises, develops and exists. Conditions are interpreted as "necessary circumstances, features of reality that allow the implementation, creation, formation of something or contribute to something" [3].

Thus, we have determined that the condition is a necessary factor of any activity, under the influence of which the formation and further development of qualities, skills and other necessary inclinations, the influence of which is mediated by the internal activity of the individual. 
Aims. Is to determine the specifics and disclosure of the essence of the concepts "condition" and "pedagogical condition" of the formation of values to the living nature of middle school students.

Methods. In the process of research work a set of methods of scientific and pedagogical research was applied, in particular: analysis, synthesis, comparison, systematization and generalization, mathematical and statistical method.

Results. V. Andreev understands under the pedagogical condition the circumstances of the process of teaching and education, which are the result of purposeful selection, design and application of elements of content, methods, and organizational forms of learning to achieve didactic goals [4].

According to O. Brazhnych, pedagogical conditions are characterized as a set of opportunities (content, methods, organizational forms, material opportunities) for the implementation of the pedagogical process, which ensures the successful achievement of the goal [5].

R.V. Sopivnyk interprets pedagogical conditions as objective and subjective requirements and prerequisites in the implementation of which the teacher achieves the goal of his work, and at the same time rationally use forces and means. Conditions - a kind of environment, the environment in which the pedagogical influence on the pupil. The environment defines the relationships and connections necessary for the effective implementation of educational goals [6].

For O. Pekhota, pedagogical conditions are a set of certain forms, methods, material conditions, real situations that have objectively developed or were subjectively created, which are necessary to achieve a specific pedagogical goal [7].

According to research A.P. Galaeva to improve the quality of educational activities are influenced by the following factors: organizational, economic, social and personal, and pedagogical conditions are perceived as consciously constructed by the teacher circumstances that significantly affect the pedagogical process [8].

G. Ponomareva interprets the system of pedagogical conditions as a means of educational and educational influence on the feelings, mind and behavior of students [9]. According to IV Companion, pedagogical conditions - are the circumstances on which depends the achievement of educational goals [10].

According to N. Negruts' research, pedagogical conditions include: mastering by teachers of the theory of bases of formation of the value relation to the living nature; their acquisition of the ability to choose effective methods of organizing the educational process, which is aimed at the formation and development of knowledge and mastery of practical skills for the implementation of values to the living nature of students; organization of various activities of middle school students aimed at the development of values in relation to wildlife [11].

According to V. Manko, pedagogical conditions are characterized by a set of internal and external characteristics of functioning, which provide high efficiency of the educational process and meet the psychological and pedagogical criteria of optimality [12].

Summarizing the different approaches to the interpretation of the concept of "pedagogical conditions", we can determine that these are certain circumstances, 
objective and subjective factors of the initial process, namely: the subject, teaching and learning that are necessary to ensure effective functioning of all components of the education system in direct dependence on the purposes, tasks, the maintenance, forms and methods of this system.

Thus, we can attribute to the pedagogical conditions those factors and circumstances of the educational process that meet certain requirements, namely: have a clear structure, logical sequence of elements that form the necessary connections and promote more effective formation of the necessary qualities in the educational process.

Based on the above, we can formulate our own definition of pedagogical conditions for educating values of wildlife of middle school students, which means a set of interrelated circumstances and factors of the educational process that affect its course and aimed at developing a harmoniously developed personality with clearly formed ecological knowledge, skills and abilities regarding the value attitude to the living nature, personal-value attitudes towards the readiness for nature protection activity and the corresponding style of thinking.

O.O. Kolonkova identified the following pedagogical conditions for the value attitude to wildlife of high school students: the subordination of the process of educating the value attitude to nature in high school students to the purpose of personal development; harmonization of educational influence of natural and social environment; taking into account the specifics of the rural and urban environment of development and formation [13].

O.I. Terentyev, as a result of research of the problem of education of the value relation to the living nature allocates the following pedagogical conditions: mastering of knowledge about value of the nature which are a basis of understanding of modern ecological problems; creation of ecological and development environment in the educational institution, which would promote their application in practice; use of personality-oriented methods of pedagogical interaction; friendly relations between all participants in the educational process, the perception of the teacher who carries out the process of forming a valued attitude to the environment [14].

Discussion. To determine the pedagogical conditions in our study, we used mathematical and statistical analysis of the method of expert evaluation, the essence of which is to assess and determine the need in writing by specialists (teachers of secondary education) pedagogical conditions for educating values of wildlife on the following scale: very important "," important "," unimportant "and" has no effect at all ". The experts were 22 pedagogical employees of general secondary education institutions. Each pedagogical condition, which received a grade of "very important" was evaluated by us in 3 points, "important" - 2 points, "unimportant" - 1 point and "has no effect" - 0 points. The results of the expert assessment are shown in table 1. 
Table 1. The results of an expert survey to determine the pedagogical conditions for the education of values to the living nature of middle school students

\begin{tabular}{|c|c|c|c|c|}
\hline № & Pedagogical conditions & $\begin{array}{l}\text { The sum } \\
\text { of points }\end{array}$ & Rank & $\begin{array}{c}\text { Coefficient of } \\
\text { weight }\end{array}$ \\
\hline 1. & $\begin{array}{l}\text { Transfer of knowledge about wildlife and patterns of } \\
\text { the world to middle school students }\end{array}$ & 56 & 2 & \\
\hline 2. & $\begin{array}{l}\text { Practical and methodical preparation of class teachers } \\
\text { for the education of values to the living nature of } \\
\text { middle school students }\end{array}$ & 50 & 4 & \\
\hline 3. & $\begin{array}{l}\text { Organization of excursions for middle school } \\
\text { students by leading organizations in environmental } \\
\text { protection }\end{array}$ & 47 & 6 & \\
\hline 4. & $\begin{array}{l}\text { Formation of a value attitude to the living nature of } \\
\text { middle school students in the student body }\end{array}$ & 45 & 7 & \\
\hline 5. & $\begin{array}{l}\text { Formation of environmentally friendly skills } \\
\text { behavior in the process of everyday life }\end{array}$ & 44 & 8 & \\
\hline 6. & $\begin{array}{l}\text { Motivation of middle school students to self- } \\
\text { education of careful attitude to wildlife and rational } \\
\text { use of nature }\end{array}$ & 45 & 7 & \\
\hline 7. & $\begin{array}{l}\text { Application of the method of example in the } \\
\text { formation of values to wildlife }\end{array}$ & 44 & 8 & \\
\hline 8. & $\begin{array}{l}\text { Creation of optional classes and special courses } \\
\text { aimed at educating values of wildlife of middle } \\
\text { school students }\end{array}$ & 51 & 3 & \\
\hline 9. & $\begin{array}{l}\text { Involvement of middle school students in collective } \\
\text { activities aimed at caring for wildlife }\end{array}$ & 45 & 7 & \\
\hline 10. & $\begin{array}{l}\text { Use of interactive forms and methods of ecological } \\
\text { educational work orientation }\end{array}$ & 58 & 1 & \\
\hline 11. & $\begin{array}{l}\text { Systematic inclusion of middle school students in } \\
\text { activities dedicated to the formation of a valued } \\
\text { attitude to wildlife }\end{array}$ & 48 & 5 & \\
\hline 12. & $\begin{array}{l}\text { Involvement of middle school students in the } \\
\text { activities of environmental NGOs }\end{array}$ & 44 & 8 & \\
\hline 13. & The use of art in the education of values to wildlife & 41 & 9 & \\
\hline 14. & $\begin{array}{l}\text { Organizing meetings with successful people who } \\
\text { promote values to wildlife }\end{array}$ & 31 & 10 & \\
\hline
\end{tabular}

Conclusion. As a result of reviewing the scientific literature, mathematical and statistical analysis of the results of expert evaluation, we have identified significant pedagogical conditions for the education of values to wildlife of middle school students, namely:

1) the use of interactive forms and methods of educational work of ecological orientation;

2) the transfer of knowledge about wildlife and the laws of existence of the world;

3) creation of optional classes and special courses aimed at educating the values of wildlife of middle school students;

4) practical and methodical preparation of class teachers for the education of values to the living nature of middle school students; 
5) systematic inclusion of middle school students in activities dedicated to the formation of a valued attitude to wildlife.

In our opinion, such an algorithm of answers of expert teachers is connected with teachers' understanding of the importance and importance of creating positive conditions for education and formation of values in relation to wildlife.

It is more expedient to carry out methodical bases of education of the value relation to a wildlife of pupils of average school age, being guided by criteria of the corresponding pedagogical conditions. Namely: the use of interactive forms and methods of educational work of ecological orientation; transfer of knowledge about wildlife and patterns of existence of the world; creation of optional classes and special courses aimed at educating the values of wildlife of middle school students; practical and methodical preparation of class teachers for the education of values to the living nature of middle school students; systematic inclusion of middle school students in activities aimed at forming a valued attitude to wildlife. Due to this, the paradigm of integrity and unity of scientific knowledge and their practical implementation in everyday life is preserved. Based on the analysis of these criteria and levels of this personal education, we formulated the statement that the use of different methods and techniques together would be pedagogically appropriate and justified in the educational environmental process of middle school students.

\section{References:}

1. Semenova, A. V. (Red.). (2006), Slovnyk-dovidnyk z profesiynoyi pedahohiky. [Dictionary-reference book on professional pedagogy], Odesa: Pal'mira [in Ukrainian].

2. Filosofskiy entsiklopedicheskiy slovar' (1983), [Philosophical encyclopedic dictionary], M .: Sov. Encyclical.

3. Ukrayins'kyy Radyans'kyy Entsyklopedychnyy Slovnyk: v 3 t. (1987), [Ukrainian Soviet Encyclopedic Dictionary: in 3 volumes], K. : Hol. red. URE.

4. Andreev, V.I. (2006), Pedagogika: uchebnyy kurs dlya tvorcheskogo samorazvitiya. [Pedagogy: a training course for creative self-development]. Kazan: Center for Innovative Technologies.

5. Brazhnich, O. G. (2001), Pedahohichni umovy dyferentsiyovanoho navchannya uchniv zahal'noosvitn'oyi shkoly. [Pedagogical conditions of differentiated education of secondary school students].

6. Sopivnyk, RV (2014), Kurs lektsiy z pedahohiky (dlya studentiv napryamu pidhotovky «Filolohiya»). [Course of lectures on pedagogy (for students majoring in "Philology"). Kyiv: Central Committee "Comprint"].

7. Pyekhota, O. M. (2003), Pidhotovka maybutn'oho vchytelya do vprovadzhennya pedahohichnykh tekhnolohiy. [Preparing future teachers for the introduction of pedagogical technologies]. Kyyiv.: V-vo A. S. K.

8. Halyeyeva, A. P. (2007), Orhanizatsiyno-pedahohichni umovy vdoskonalennya vykhovnoyi diyal'nosti u vyshchykh ahrarnykh navchal'nykh zakladakh. [Organizational and pedagogical conditions for improving educational activities in higher agricultural educational institutions]. Hesiod. Trudy i dni.

9. Sopivnyk, I. V. (2014), Vykhovannya moral'noyi vidpovidal'nosti sil's'koyi molodi. [Education of moral responsibility of rural youth]. Kyyiv: Lohos.

10.Nehrutsa, N. A. (2003), Formuvannya ekolohichnoho svitohlyadu studentiv vyshchykh navchal'nykh zakladiv I-II rivniv akredytatsiyi ahrarnoho profilyu u protsesi vyvchennya ekonomichnykh dystsyplin. [Formation of ecological worldview of students of higher educational institutions of I-II levels of accreditation of agrarian profile in the process of studying economic disciplines]. Instytut pedahohichnoyi i psykholohichnoyi profesiynoyi osvity APN Ukrayiny.

11.Man'ko, V. M. (2000), Dydaktychni umovy formuvannya u studentiv profesiyno-piznaval'noho interesu do spetsial'nykh dystsyplin. [Didactic conditions for the formation of students' professional and cognitive interest in special disciplines]. Kyyiv: Lohos.

12.Kolon'kova, O. O. (2003), Vykhovannya u starshoklasnykiv tsinnisnoho stavlennya do pryrody. [Education of high school students values of nature].Instytut problem vykhovannya APN Ukrayiny. Kyyiv. 
13. Terent'eva, L. Y. (n.d.), Formyrovanye u studentov tsennostnoho otnoshenyya k pryrode $v$ protsesse ékolohycheskoho obrazovanyya. [Formation of students' value attitude to nature in the process of environmental education]. Naukova biblioteka dysertatsiy $i$ avtoreferativ. Retrieved from: http: //www.dissercat.com/content/form irovanie-u-studentov-tsennostnogo-otnosheni.

Received: August 28, 2021 Approved: September 26, 2021 